\title{
S100B and delirium in the geriatric acute care setting
}

\author{
Walaa W. Aly ${ }^{1}$, Samia A. Abdul-Rahman ${ }^{1}$, Salma M. S. El Said ${ }^{1}$, Samah A. Bastawy ${ }^{2}$ \\ ${ }^{1}$ Department of Geriatrics and Gerontology, Ain Shams University, Cairo, Egypt; \\ *Corresponding Author: walaawessam@yahoo.com \\ ${ }^{2}$ Department of Clinical Pathology, Cardiothoracic Surgical Center, Ain Shams University Hospitals, Cairo, Egypt
}

Received 18 July 2013; revised 18 August 2013; accepted 25 August 2013

Copyright (c) 2014 Walaa W. Aly et al. This is an open access article distributed under the Creative Commons Attribution License, which permits unrestricted use, distribution, and reproduction in any medium, provided the original work is properly cited. In accordance of the Creative Commons Attribution License all Copyrights (C) 2014 are reserved for SCIRP and the owner of the intellectual property Walaa W. Aly et al. All Copyright (C) 2014 are guarded by law and by SCIRP as a guardian.

\section{ABSTRACT}

Delirium and its relation to biochemical markers have been considered a study question in several research works. The relation between S100B levels and delirium is still a matter of discussion. Objective: To compare the serum level of S100B in patients with and without delirium and to detect the relation between S100B and delirium subtypes. Method: A case control study was conducted on 114 elderly (60 years and older) selected from the geriatric acute care unit at Ain Shams University Hospitals. They were classified into two groups; 58 elderly cases who had delirium diagnosed by Confusion Assessment Method and 56 controls. Then delirium was reclassified according to the subtypes of delirium into Hyperactive: 46 patients, hypoactive: 2 patients, and Mixed: 10 patients. Serum S100B levels were determined by ELISA. Results: Cases were significantly older than controls $(72.4 \pm 9.4$ versus $66.9 \pm 5.3$ years respectively) $(P<0.001)$. S100B levels were higher in cases (32.4 \pm 9.8 $\mathrm{pg} / \mathrm{ml})$ than controls $(30 \pm 9.3 \mathrm{pg} / \mathrm{ml})$ but the difference was not statistically significant $(P=0.19)$. There was no significant difference in S100B levels between the different subtypes of delirium. Conclusion: Delirious patients had higher S100B levels than controls but the difference was not statistically significant.

\section{KEYWORDS}

Delirium; S100B; Elderly

\section{INTRODUCTION}

Delirium is a common clinical syndrome characterized by inattention and acute cognitive dysfunction. Delirium affects $14 \%$ - 56\% of the elderly hospitalized patients [1].

Most literature about delirium emphasizes the problem of poor identification of delirium by hospital physicians. Hypoactive rather than hyperactive delirium is particularly missed because of the seemingly non-alarming symptoms [2].

Delirium is associated with poor outcomes as morbidity, longer hospital stays, functional decline and even mortality $[3,4]$.

Despite these serious effects on outcome, the pathogenesis of delirium is still incompletely understood [5].

Delirium is thought to be the result of alterations in neurotransmission, inflammation, and/or cerebral blood flow [6]. These alterations could be associated with cell death in the central nervous system (CNS), but there is no direct evidence of neuron/glial cell death in delirious patients [7].

S100B-protein (S100B) is a dimeric calcium-binding protein with $\alpha$ and $\beta$ subunits; the $\beta$ subunit is highly specific to the brain [7] and can be used as a biomarker of glial and neuronal damage in patients with a variety of illnesses [8].

S100B is considered a marker of brain damage in various diseases [9]. It is expressed mainly by astrocytes and is found both intra- and extra-cellularly in brain tissue. It is usually elevated in nervous system damage both in CSF and blood, due to functional disturbance of membrane integrity and/or increased permeability of the bloodbrain barrier [10].

Many studies found elevated levels of S100B in delirious patients with highest levels of S100B being in samples taken after delirium subsides [11], and that S100B levels were significantly higher in delirious patients when compared to non-delirious controls [12].

Elevated levels of S100B have been shown to be associated with delirium in patients after abdominal surgery [13], cardiac surgery [14], hip fracture surgery [15] and in sepsis-related delirium [16]. 
Van Munster and colleagues [12] compared S100B, cortisol, and IL6 and found S100B to be the strongest independent marker of post hip fracture surgery delirium after adjusting for pre-existing cognitive impairment.

The Aim of the present study is to compare the serum level of S100B in patients with and without delirium and to detect the relation between S100B and delirium subtypes.

\section{SUBJECTS AND METHODS}

Study design: Case-control.

Study setting: Ain Shams University hospitals.

The study was approved by the ethical committee of the Faculty of Medicine, Ain Shams University.

Informed consent was taken from controls and from surrogates in cases.

\subsection{Study Population}

Participants were 114 elderly inpatients in the Geriatric acute care unit (58 consecutive patients with delirium diagnosed by Confusion Assessment Method and 56 sex matched controls).

Delirious patients were reclassified according to the subtypes of delirium into hyperactive: 46 patients, hypoactive: 2 patients, and mixed delirium: 10 patients.

Comprehensive geriatric assessment was done for each patient within the first 24 hours after admission and the presence or absence of delirium was assessed using the Confusion Assessment Method (CAM) [17].

Possible causes of delirium in the case group and cause of admission in the control group as well as the number of comorbidities were registered. Investigations including ECG, random blood sugar, electrolytes, CBC, liver and kidney functions to evaluate the causes of delirium and/or cause of admission were done.

Venous samples for S100B measurement were taken in the first 24 hours of admission. Laboratory assay of serum protein S100B was done using ELISA technique (Human S100B ELISA kit) on Stat Fax ELISA reader.

\subsection{Exclusion Criteria}

Patients who had aphasia or were in coma or were not able to communicate for any reason.

\subsection{Statistical Analysis}

Data collected is described in the form of frequency distribution tables (number and percentages) for categorical variables. Chi square test was used to test the association between categorical variables. Comparison between two independent mean groups for parametric data was done using Student t test. ANOVA test was used to compare different S100B levels among different types and causes of delirium. The probability of error at 0.05 was considered significant, while at 0.01 and 0.001 were highly significant. All statistical manipulation was carried out using the 15th version of SPSS (SPSS, Chicago, IL, USA).

\section{RESULTS}

The study is a case-control study which was conducted on 114 elderly, 58 (51\%) of patients had delirium (cases) while 56 (49\%) of patients did not have delirium (controls).

Patients with delirium were significantly older than patients without delirium (controls) $(72.4 \pm 9.4$ versus $66.9 \pm 5.3$ years $)(\mathrm{P}<0.001)$. However, there was no significant gender difference between delirious and nondelirious participants (Table 1).

There was a higher prevalence of illiteracy in cases 38 (65.5\%) than in controls 24 (42.9\%) with a statistically significant difference $(\mathrm{P}=0.02)$.

Mean S100B levels were higher in cases (32.4 \pm 9.8 $\mathrm{pg} / \mathrm{ml})$ than in controls $(30 \pm 9.3 \mathrm{pg} / \mathrm{ml})$ but the difference was not of statistical significance $(P=0.19)$.

Comparison between cases and controls regarding causes of hospital admission revealed higher frequency of cerebrovascular stroke 24 (41.3\%), infections 12 (21\%) and lower frequency of Hepatic encephalopathy 2 (3.4\%), Myocardial infarction 2 (3.4\%) in cases, while in the control group, there was a higher frequency of heart failure 22 (39.3\%) then infection 12 (21.4\%) and a lower frequency of stroke 2 (3.6\%) and dehydration 2 (3.6\%) with a highly significant difference between cases and controls ( $\mathrm{P}<0.001)$ (Table 2).

When correlating S100B levels to the different subtypes of delirium (Hyperactive: 46 patients, hypoactive: 2 patients, or Mixed: 10 patients), no statistical difference was found ( $\mathrm{P}=0.169$ ) (Table 3 ).

On the other hand, correlation to the main cause of hospital admission revealed higher mean levels of S100B in cases with infectious diseases (38.5), followed by those with treatment refusal (35.2), patients with hepatic encephalopathy (34), cerebrovascular stroke (33.2) and lastly patients with shock who had the lowest mean S100B levels (22.3) and that difference was statistically significant ( $\mathrm{P}=0.02)$ (Table 4).

By correlating S100B levels and comorbidities among cases and controls, it was evident that the highest mean S100B levels were found in patients with Liver cell failure $(38 \pm 4.62)$ then in patients with ischemic heart disease $(36.6 \pm 10.1)$ while patients without comorbidities had the lowest S100B levels $(26 \pm 8)$ with a difference that was statistically significant $(P=0.04)$ (Table 5).

\section{DISCUSSION}

This study like other studies comparing delirious 
Table 1. Demographic characteristics of patients with and without delirium.

\begin{tabular}{ccccc}
\hline \multirow{2}{*}{ Demographic data } & $\begin{array}{c}\text { Delirium } \\
(\mathrm{N}=58)\end{array}$ & $\begin{array}{c}\text { No Delirium } \\
(\mathrm{N}=56)\end{array}$ & P value \\
\hline \multirow{2}{*}{ Age in years } & & $72.4( \pm 9.4)$ & $66.9( \pm 5.3)$ & 0.000 \\
Sex $^{* *}$ & Males & $28(50 \%)$ & $28(50 \%)$ & 0.85 \\
Education $^{* *}$ & Females & $30(52 \%)$ & $28(48 \%)$ & \\
& Illiterate & $38(65.5 \%)$ & $24(42.9 \%)$ & \\
& Can read \& write & $14(24.1 \%)$ & $14(25 \%)$ & 0.02 \\
& $<6$ years & $2(3.5 \%)$ & $10(17.9 \%)$ & \\
Smoking $^{* * *}$ & $>6$ years & $4(6.9 \%)$ & $8(14.2 \%)$ & \\
& Smoker & $8(13.8 \%)$ & $10(17.9 \%)$ & 0.61 \\
& Non Smoker & $38(65.5 \%)$ & $38(67.9 \%)$ & \\
S100B $^{*}$ & Ex Smoker & $12(20.7 \%)$ & $8(14.2 \%)$ & \\
\hline
\end{tabular}

*Expressed as mean (SD); ${ }^{* *}$ Expressed as No. (\%).

Table 2. Comparison between patients with and without delirium as regard the main cause of hospital admission.

\begin{tabular}{cccc}
\hline $\begin{array}{c}\text { Main cause } \\
\text { of admission }\end{array}$ & $\begin{array}{c}\text { Delirium } \\
(\mathrm{N}=58) \\
\text { No. }(\%)\end{array}$ & $\begin{array}{c}\text { No Delirium } \\
(\mathrm{N}=56) \\
\text { No. }(\%)\end{array}$ & P value \\
\hline Stroke & $24(41.3 \%)$ & $2(3.6 \%)$ & \\
Infections & $12(21 \%)$ & $12(21.4 \%)$ & \\
Dehydration & $4(6.9 \%)$ & $2(3.6 \%)$ & \\
HF & $0(0 \%)$ & $22(39.3 \%)$ & \\
DKA & $2(3.4 \%)$ & $2(3.6 \%)$ & 0.000 \\
Shock & $6(10.3 \%)$ & $3(5.3 \%)$ & \\
Treatment refusal & $6(10.3 \%)$ & $3(5.3 \%)$ & \\
MI & $2(3.4 \%)$ & $4(7.2 \%)$ & \\
Hepatic & $2(3.4 \%)$ & $6(10.7 \%)$ & \\
encephalopathy & & $56(100 \%)$ & \\
Total & $58(100 \%)$ & 56 &
\end{tabular}

HF: Heart failure, DKA: Diabetic ketoacidosis, MI: Myocardial infarction.

Table 3. ANOVA Test to compare the different S100B levels among different types of delirium.

\begin{tabular}{ccccc}
\hline S100B & No. & Mean (SD) & F & P value \\
\hline Hyperactive & 46 & $32.2(10.4)$ & & \\
Hypoactive & 2 & $45(0)$ & & \\
Mixed & 10 & $31(5.3)$ & 1.84 & 0.169 \\
Total & 58 & $32.4(9.8)$ & & \\
\hline
\end{tabular}

patients to non-delirious controls found that delirious patients are usually older, sometimes this finding reaches statistical significance as found by van Munster et al. [11] and other times not [18]. The cases in this study were significantly older $(72.4 \pm 9.4)$ than the controls $(66.9 \pm$ 5.3) years.

One interesting finding here is the comparison between the causes of admission among cases and controls and the significant influence of those causes of admis-
Table 4. ANOVA Test to compare the different S100B levels among different causes of delirium.

\begin{tabular}{cccccc}
\hline Main cause of admission & No. & Mean & SD & F & P value \\
\hline Stroke & 24 & 33.2 & 10 & & \\
Infection & 12 & 38.5 & 9.7 & & \\
Dehydration & 4 & 28.5 & 6.6 & & \\
DKA & 2 & 25 & 0 & & \\
Shock & 6 & 22.3 & 2.3 & & 0.02 \\
Treatment refusal & 6 & 35.2 & 9.8 & 2.7 & \\
MI & 2 & 22.5 & 3.5 & & \\
Hepatic encephalopathy & 2 & 34 & 0 & & \\
Total & 58 & 32.4 & 9.8 & & \\
\hline
\end{tabular}

DKA: Diabetic ketoacidosis, MI: Myocardial infarction.

Tab le 5. ANOVA Test for comparison of different S100B levels in relation to history of medical comorbidities.

\begin{tabular}{cccccc}
\hline Comorbidities & No. & Mean & SD & F & P value \\
\hline No & 16 & 26 & 8 & & \\
DM & 50 & 30.5 & 8.7 & & \\
HTN & 28 & 33.8 & 8.9 & 2.39 & \\
ISHD & 7 & 36.6 & 10.1 & & 0.04 \\
CHF & 9 & 30 & 11.5 & & \\
LCF & 4 & 38 & 4.62 & & \\
\hline
\end{tabular}

DM: Diabetes mellitus, HTN: Hypertension, ISHD: Ischemic heart disease, CHF: Congestive heart failure, LCF: Liver cell failure.

sion on the mean levels of S100B. Higher frequency of cerebrovascular stroke and infections were observed among cases and significantly higher mean levels of S100B in cases admitted with infectious diseases than those admitted for other causes. Unden et al. [19] found that $73 \%(8 / 11)$ of patients with bacterial meningitis showed increased levels of S100B compared to 7\% (1/14) of patients with viral meningitis and that viral encephalitis showed the highest mean S100B levels (mean $0.58 \mathrm{mi}-$ crog/l). 25\% (6/24) of patients with extra-cerebral infections showed raised S100B levels. S100B levels were generally higher in patients with cerebral infections than in extra-cerebral infections [19].

While van Munster et al. [11] found a higher frequency of infectious diseases and a lower frequency of dehydration and electrolyte disturbances in delirious compared to non-delirious participants $(\mathrm{P}<0.001)$.

The exact mechanism responsible for the S100B increase had been studied in several studies $[13,14,16]$. Of their explanations to the increase in serum S100B levels, cerebral or extra-cerebral cellular damage, increased permeability of the BBB, and up-regulation of S100B production by astrocytes are the main $[20,21]$.

The fact that the level of S100B is highest after delirium, may indicate that not cerebral damage, but active stimulation of astrocytes or increased permeability of the $\mathrm{BBB}$ are the principal causal mechanisms for the in- 
crease [22].

Unden and colleagues [19] found that patients with extra-cerebral infections showed raised S100B levels, which could indicate both an extra-cerebral source of S100B as well as increased release of S100B from astrocytes as a brain response to pro-inflammatory cytokines. Positive correlations between serum S100B levels with lymphocyte and granulocyte counts, both induced by cytokines, have been described in noninfectious acute care patients as well Kleine et al. [23] but this was not assessed in this study.

We did not find a difference in S100B levels between the different subtypes of delirium nor did van Munster and colleagues [11] who studied 412 patients and found the same result. This might possibly be due to the small numbers of patients in the different subgroups, and whether there is a difference between subtypes it needs to be established on a larger sample.

On the contrary to many other studies, in this study S100B - despite being higher in cases than controls — but the difference was not statistically significant, van Munster et al. [11] found S100B levels to be significantly higher among delirious patients when compared to nondelirious ones.

A limitation of our study is that S100B values were measured in peripheral blood and may not necessarily correspond to values in the brain. Under normal conditions serum S100B levels are lower than that in cerebrospinal fluid (CSF). A second limitation is that only one blood sample is available during the $24 \mathrm{~h}$ period, and the half-life of S100B in the blood is less than $2 \mathrm{~h}$, while Foerch et al. [24] studied 51 elderly patients admitted within 6 hours after stroke symptom onset caused by proximal MCA occlusion. Serum S100B concentrations were determined at hospital admission and 8, 12, 16, 20, and 24 hours after symptom onset. Foerch et al. [24] found that a 12-hour S100B value $>0.35 \mu \mathrm{g} / \mathrm{L}$ predicted malignant infarction with 0.75 sensitivity and 0.80 specificity and a 24-hour value $>1.03 \mu \mathrm{g} / \mathrm{L}$ provided 0.94 sensitivity and 0.83 specificity.

\section{REFERENCES}

[1] Fong, T.G., Tulebaev, S.R. and Inouye, S.K. (2009) Delirium in elderly adults: diagnosis, prevention and treatment. Nature Reviews Neurology, 5, 210-220.

[2] Lyons, W.L. (2006) Delirium in post acute and long-term care. Journal of the American Medical Directors Association, 7, 254-261. http://dx.doi.org/10.1016/j.jamda.2005.11.003

[3] Cole, M.G. and Primeau, F.J. (1993) Prognosis of delirium in elderly hospital patients. Canadian Medical Association Journal, 149, 41-46.

[4] Francis, J. and Kapoor, W.N. (1992) Prognosis after hos- pital discharge of older medical with delirium. Journal of the American Geriatric Society, 40, 601-606.

[5] Maclullich, A.M., Ferguson, K.J., Miller, T., de Rooij, S.E. and Cunningham, C. (2008) Unraveling the pathophysiology of delirium: A focus on the role of aberrant stress responses. Journal of Psychosomatic Research, 65, 229-238. http://dx.doi.org/10.1016/j.jpsychores.2008.05.019

[6] Gunther, M.L., Morandi, A. and Ely, E.W. (2008) Pathophysiology of delirium in the intensive care unit. Critical Care Clinics, 24, 45-65.

http://dx.doi.org/10.1016/j.ccc.2007.10.002

[7] Lewin, G.R. and Barde, Y.A. (1996) Physiology of the neurotrophins. Annual Review of Neuroscience, 19, 289317. http://dx.doi.org/10.1146/annurev.ne.19.030196.001445

[8] Kochanek, P.M., Berger, R.P., Bayir, H., Wagner, A.K., Jenkins, L.W. and Clark, R.S. (2008) Biomarkers of primary and evolving damage in traumatic and ischemic brain injury: Diagnosis, prognosis, probing mechanisms, and therapeutic decision making. Current Opinion in Critical Care, 14, 135-41. http://dx.doi.org/10.1097/MCC.0b013e3282f57564

[9] Goncalves, C.A., Leite, M.C. and Nardin, P. (2008) Biological and methodological features of the measurement of S100B, a putative marker of brain injury. Clinical Biochemistry, 41, 755-763.

http://dx.doi.org/10.1016/j.clinbiochem.2008.04.003

[10] Basile, A.M., Fusi, C., Conti, A.A., Paniccia, R., Trefoloni, G., Pracucci, G., Di Carlo, A., Noferi, D., Carbonetto, F., Pretelli, P., Calamai, G., Vaccari, M., Abbate, R. and Inzitari, D. (2001) S-100 protein and neuron-specific enolase as markers of subclinical cerebral damage after cardiac surgery: Preliminary observation of a 6-month follow-up study. European Neurology, 45, 151-159. http://dx.doi.org/10.1159/000052114

[11] van Munster, B.C., Korevaar, J.C., Korse, C.M., Bonfrer, J.M., Zwinderman, A.H. and de Rooij, S.E. (2010) Serum S100B in elderly patients with and without delirium. International Journal of Geriatric Psychiatry, 25, 234-239. http://dx.doi.org/10.1002/gps.2326

[12] van Munster, B.C., Bisschop, P.H., Zwinderman, A.H., Korevaar, J.C., Endert, E., Wiersinga, W.J., van Oosten, H.E., Goslings, J.C. and de Rooij, S.E. (2010) Cortisol, interleukins and S100B in delirium in the elderly. Brain and Cognition, 74, 18-23. http://dx.doi.org/10.1016/j.bandc.2010.05.010

[13] Rasmussen, L.S., Christiansen, M., Rasmussen, H., Kristensen, P.A. and Moller, J.T. ISPOCD Group (2000) Do blood concentrations of neurone specific enolase and S100 beta protein reflect cognitive dysfunction after abdominal surgery? British Journal of Anaesthesia, 84, 242244. http://dx.doi.org/10.1016/j.bandc.2010.05.010

[14] Herrmann, M., Ebert, A.D., Galazky, I., Wunderlich, M.T., Kunz, W.S. and Huth, C. (2000) Neurobehavioral outcome prediction after cardiac surgery: Role of neurobiochemical markers of damage to neuronal and glial brain tissue. Stroke, 31, 645-650. http://dx.doi.org/10.1161/01.STR.31.3.645

[15] van Munster, B.C., Korse, C.M., de Rooij, S.E., Bonfrer, 
J.M., Zwinderman, A.H. and Korevaar, C. (2009) Markers of cerebral damage during delirium in elderly patients with hip fracture. BMC Neurology, 9, 21.

http://dx.doi.org/10.1186/1471-2377-9-21

[16] Pfister, D., Siegemund, M., Dell-Kuster, S., Smielewski, P., Rüegg, S., Strebel, S.P., Marsch, S.C., Pargger, H. and Steiner, L.A. (2008) Cerebral perfusion in sepsis-associated delirium. Critical Care, 12, R63. http://dx.doi.org/10.1186/cc6891

[17] Inouye, S.K., van Dyck, C.H., Alessi, C.A, Balkin, S., Siegal, A.P. and Horwitz, R.I. (1990) Clarifying confusion: The Confusion Assessment Method. A new method for detection of delirium. Annals of Internal Medicine, 113, 941-948.

[18] Lawlor, P.G., Gagnon, B., Mancini, I.L., Pereira, J.L., Hanson, J., Suarez-Almazor, M.E. and Bruera, E.D. (2000) Occurrence, causes, and outcome of delirium in patients with advanced cancer: A prospective study. Archives of Internal Medicine, 160, 786-794. http://dx.doi.org/10.1001/archinte.160.6.786

[19] Unden, J., Christensson, B., Bellner, J., Alling, C. and Romner, B. (2004) Serum S100B levels in patients with cerebral and extracerebral infectious disease. Scandinavian Journal of Infectious Diseases, 36, 10-13. http://dx.doi.org/10.1080/00365540310017294

[20] Townend, W., Dibble, C., Abid, K., Vail, A., Sherwood, R. and Lecky, F. (2006) Rapid elimination of protein S-100B from serum after minor head trauma. Journal of Neurotrauma, 23, 149-155.

http://dx.doi.org/10.1089/neu.2006.23.149

[21] Donato, R., Sorci, G., Riuzzi, F., Arcuri, C., Bianchi, R., Brozzi, F., Tubaro, C. and Giambanco, I. (2009) S100B's double life: Intracellular regulator and extracellular signal. Biochimica et Biophysica Acta, 1793, 1008-1022. http://dx.doi.org/10.1016/j.bbamcr.2008.11.009

[22] van Munster, B.C., Korevaar, J.C., Zwinderman, A.H., Levi, M., Wiersinga, W.J. and de Rooij, S.E. (2008) Timecourse of cytokines during delirium in elderly patients with hip fractures. Journal of the American Geriatrics Society, 56, 1704-1709. http://dx.doi.org/10.1111/j.1532-5415.2008.01851.x

[23] Kleine, T.O., Benes, L. and Zofel, P. (2003) Studies of the brain specificity of S100B and neuron-specific enolase (NSE) in blood serum of acute care patients. Brain Research Bulletin, 61, 265-279. http://dx.doi.org/10.1016/S0361-9230(03)00090-X

[24] Foerch, C., Otto, B., Singer, O.C., Neumann-Haefelin, T., Yan, B., Berkefeld, J., Steinmetz, H. and Sitzer, M. (2004) Serum S100B predicts a malignant course of infarction in patients with acute middle cerebral artery occlusion. Stroke, 35, 2160-2164. http://dx.doi.org/10.1161/01.STR.0000138730.03264.ac 